\title{
10 An Efficient Protocol Of Stevia rebaudiana Regeneration For Large-Scale Production
}

\author{
A. S. Attaya ${ }^{\#}$ \\ Department of Plant Production, Faculty of Environmental Agricultural Sciences, \\ Arish University, North Sinai, Egypt.
}

Received: $30 / 11 / 2016$ Accepted: 27/4/2017
Stevia rebaudiana is considered a valuable natural sweetener and medicinal plant $\checkmark$ containing sweetener compounds in its leaves. Nowadays, plant drugs are frequently considered to be free from side effects and less toxic than the synthetic one, for that people and some pharmacological companies are heading to the herbal medicine. Thus, to meet the increased demand for raw material of this medicinal herb, I described in this study an efficient regeneration protocol using shoot tip and nodal explants and different PGRs on MS medium for healthy biomass production. The optimum shoot growth with a high number without callus formation was obtained using MS medium in the presence of $1.0 \mathrm{mgL}^{-1} \mathrm{BA}$ after 6 weeks which shows (4.06-4.46) shoot buds/explant after 6 weeks. The combination of $1.0 \mathrm{mg} \mathrm{L}^{-1} \mathrm{BA}$ with $0.5 \mathrm{mg} \mathrm{L}^{-1} \mathrm{IBA}$ was found to be best combination for shoot multiplication that recorded 6.66 shoots/explant with $4.46 \mathrm{~cm}$ shoot length. Healthy elongated shoots were harvested and then cultured on half strength MS basal salts medium without vitamins medium in the presence of different concentrations of IBA and NAA individual or in combination with IAA or 2,4-D. Moreover, the optimum root growth with high roots number (4.46) with (76.6 \%) root formation was observed using $1.0 \mathrm{mg} \mathrm{L}^{-1}$ IBA on half strength MS medium. Therefore, well-developed healthy in vitro rooted plantlets after 6 weeks were successfully acclimatized and they grew as normal plants in the greenhouse.

Keywords: Micro propagation, Plant growth regulators, Murashige and Skoog medium (MS), In vitro Rooting, IBA, IAA, BA

\section{INTRODUCTION}

Stevia rebaudiana Bertoni (Asteraceae family) is a perennial herb that originated from Paraguay and Brazil. It is cultivated for its sweetener compounds that accumulates in young leaves and being used as substitute to sucrose that found to be 100-300 times sweeter than it (Ahmad et al. 2011). These compounds are low-calorie, non-toxic and non-mutagenic compounds so it is being used for the treatment of diabetes (Aman et al. 2013). The stevioside can be used in cooked or baking products, tea, coffee, processed foods, beverages, fruit juices, cold drinks, pastries and chewing gum (Deshmukh \& Ade, 2012). Beside its sweet taste, antioxidant activities, anti-pathogenic, anti-cancerous, antihyperglycaemic, anti hypersensitive properties, as well as an effect in the prevention of dental caries (Kinghorn \& Soejarto, 1985 and Starratt et al., 2002). Brazilian and Paraguayan tribes used these valuable species for the treatment of heartburn in medicinal teas and Yerba mate (Singh \& Rao, 2005). Stevioside is highly recommended for diabetes, hypoglycemia, hypertension, high blood pressure, depression, cavities, fatigue, obesity, sweet craving and infections (Jeppensen et al., 2002 and Dyrskog et al., 2005).

It is being cultivated as a crop in Korea, China, Indonesia, Taiwan, Thailand, Philippines, Japan, Malaysia, Israel, Ukraine, UK, Canada, United States, Mexico, and in South America countries. Stevia plant is heterozygous and seed germination or stem cutting are not suitable approaches for healthy biomass and SGs production (Aman et al., 2013). The seeds of $S$. rebaudiana are small in size, have a poor germination rate and the seeds loose viability during storage. In addition, propagation by seeds does not allow the production of homogeneous populations, which lead to great variability in sweetening composition and its levels (Tamura et al., 1984 and Nakamura $\&$ Tamura 1985). Vegetative propagation through

\#Corresponding author email: ahmd.attaya@gmail.com 
stem cuttings is limited by the lower number of individuals that can be observed at the same time from a single plant. Thus, it needs higher input stock and also laborious (Debnath et al., 2006).

For these reasons, an efficient protocol for large-scale plant production within a short period such as using in vitro culture technology is necessary because it allows recovery of true to type progeny and genetically stable. In the past, a few tissue culture methods have been presented on $S$. rebaudiana plants using shoot tip, leaf, nodal and intermodal segments (Patil et al., 1996; Sivaram \& Mukundan, 2003; Uddin et al., 2006; Debnath, 2008; Abd Alhady, 2011; Thiyagarajan \& Venkatachalam, 2012; Aman et al., 2013 and Dey et al., 2013).

Therefore, the aim of the present study was to develop a feasible and cost-effective system for regeneration of a new sweetening crop using two types of explants (shoot tip and nodal segments) to determine which explant is most suitable for micro-propagation in the presence of different PGRs for large-scale production.

\section{MATERIALS AND METHODS}

Plant material and explant sterilization

Three-months-old Stevia rebaudiana var. spanti plants were collected and obtained from the greenhouse of Sugar Crops Research Institute, Agricultural Research Center, Ministry of Agriculture, Egypt. These experiments were conducted during the period from 2014 to 2015 at plant tissue culture lab, Faculty of Environmental Agricultural Sciences. Shoot tips and axillary nodes (1.5 cm long, $0.5 \mathrm{~cm}$ wide) were used as explants which cut, washed under running tap water and then submerged in tap water with a few drops of Tween-20 in a flask with shacking by hand for $5 \mathrm{~min}$ followed by rinsing in tap water to remove the soap. Under aseptic condition in laminar airflow hood, explants were surface sterilized with $70 \%(\mathrm{v} / \mathrm{v})$ ethanol for 30 seconds and subsequently with $0.15 \%$ mercuric chloride $\left(\mathrm{HgCl}_{2}\right)$ solution for $1 \mathrm{~min}$ followed by repeated washing (3 times) with sterile distilled water to remove all traces of $\mathrm{HgCl}_{2}$.

\section{Culture media and condition}

The sterilized explants (Shoot tip and axillary node) were trimmed $(0.5-1.0 \mathrm{~cm})$ at the base and cultured with the cut surface in contact with MS medium including basal salt mixtures and vitamins (Murashige \& Skoog, 1962) (full or half strength) supplemented with $30 \mathrm{~g} \mathrm{~L}^{-1}$ sucrose and 7 $\mathrm{g} \mathrm{L}^{-1}$ of agar. Moreover, in the presence of different concentrations of 6-Benzyladenine (BA), and Kinetin (Kin) to the previous medium to study the effect of the interaction between MS media strength, explants type and cytokinins on shoot induction of Stevia rebaudiana. 5 explants were cultured per vessel $(100 \mathrm{ml})$ as a replicate and the treatment was contained 4 vessels (4 replicates). The $\mathrm{pH}$ was adjusted to 5.6 - 5.8 before gelling with agar and autoclaved at $121^{\circ} \mathrm{C}$ and $1.1 \mathrm{~kg} \mathrm{~cm}^{-2}$ for $20 \mathrm{~min}$. then the media were distributed in vessels (30-40 $\mathrm{ml}$ for each vessel). The cultures were maintained in an air conditioned culture room at $25 \pm 2^{\circ} \mathrm{C}$ under $16 \mathrm{~h}$ per day photoperiod which provided by cool white fluorescent lamps (light intensity 2000 Lux.).

\section{In vitro rooting and hardening}

Shoots $(2-4 \mathrm{~cm})$ in length that regenerated from in vitro cultured explants were rooted on half strength MS medium. The medium was supplemented with $30 \mathrm{gL}^{-1}$ sucrose and $7 \mathrm{gL}^{-1}$ agar in the presence of different concentrations of auxins like Indole butyric acid and $\alpha$-Naphthalene acetic acid (IBA and NAA), individual or $1.0 \mathrm{mgL}^{-1}$ IBA in combination with different concentration of Indole acetic acid and 2,4-Dichlorophenoxyacetic acid (IAA and 2,4-D) to monitor the initiation and quality of adventitious roots on the regenerated shoots. 5 shoots were cultured per vessel as a replicate and the treatment was contained 4 vessels (4 replicates). The cultures were maintained under cool white fluorescent lamps provided by Philips. Then, well-rooted shoots after 4 weeks of culture were carefully taken out from the medium then washed thoroughly in sterilized distilled water for ex vitro culture. The plantlets were then planted into pots $(100 \mathrm{ml})$ containing a mixture of organic soil and sand (1:1 ratio). Then placed in a plastic tunnel and wetted with tap water followed by covering with transparent plastic bags to maintain humidity. Watering was 3 times during the 3 weeks. After that, the established plants were transplanted to black polyethylene bags containing garden soil and farmyard manure for further growth.

\section{Statistical analysis}

Statistical difference among the treatments means was analyzed by Duncan's multiple range test (DMRT) at 0.05 level using the SPSS (version 17) and the results were expressed as the mean \pm SE. Data were also subjected to analysis of variance (ANOVA). 


\section{RESULTS AND DISCUSSION}

In vitro shoot bud induction

Shoot tip and axillary node explants from 3-months-mature $S$. rebaudiana plants were cultured on MS basal medium including vitamins (full or half strength) supplemented with 30 $\mathrm{gL}^{-1}$ sucrose and $7 \mathrm{gL}^{-1}$ agar (Fig.1.A). To study the effect of the interaction between MS media strength, explants type and cytokinins on shoot induction of Stevia rebaudiana Bertoni, 1.0 $\mathrm{mgL}^{-1}$ of BA or Kin were added to the medium composition. After 6 weeks of culture, significant responses were recorded among the studied treatments. The optimum shoot induction $(93.33 \%)$ with high number of shoot buds/ explant (4.06), shoot length $(3.33 \mathrm{~cm})$ and high leaves number/shoot (3.46) were observed by using shoot tip as explants on full MS medium supplemented with $1.0 \mathrm{mgL}^{-1} \mathrm{BA}$ within a period of 6 weeks (Table 1). This result was followed by using axillary node as an explants on full MS with $1.0 \mathrm{mgL}^{-1} \mathrm{BA}$ that gave (86.66\% shoot induction) with 3.66 shoot buds, $3.10 \mathrm{~cm}$ shoot length and
3.10 leaf per explant. Moreover, using $1.0 \mathrm{mgL}^{-1} \mathrm{Kin}$ found to be third best treatment recording $76.66 \%$ shoot induction, 2.46 shoots/explant, $2.43 \mathrm{~cm}$ shoot length and 2.23 leaves/explant. In previous published works of other research groups, BA was found to be more effective than Kin for shoot bud initiation and development according to Sivaram \& Mukundan (2003) and Thiyagarajan \& Venkatachalam (2012), the preference to use $\mathrm{BA}$ as cytokinin, its degradation is slow and it can be autoclaved without losing its activity. Similar findings has been reported to study the effect of BA on multiple shoot bud induction from nodal explants in various plant species including Eclipta alba (Dhaka \& Kothari, 2005), Quercus euboica (Kartsonas \& Papafotiou, 2007), Ulmus parvifolia (Thakur \& Karnosky, 2007) and Sacostemma brevistigma (Thomas \& Shankar, 2009). The effect of MS media strength (full or half MS) were significantly differed on shoot number, shoot length and leaves number. Data in Table 1 indicate that all studied characteristics in full strength MS were significantly

TABLE 1. Effect of the interaction between media strength, explants type and cytokinins on shoot initiation of Stevia rebaudiana Bertoni after 6 weeks of culture.

\begin{tabular}{|c|c|c|c|c|c|c|}
\hline Media strength & $\begin{array}{c}\text { Explants } \\
\text { type }\end{array}$ & $\begin{array}{c}\text { PGRs } \\
\left(1 \mathrm{mgL}^{-1}\right)\end{array}$ & $\begin{array}{c}\text { Shoot } \\
\text { induction } \\
(\%)\end{array}$ & $\begin{array}{c}\text { Shoots no./ } \\
\text { explant }\end{array}$ & $\begin{array}{c}\text { Shoot } \\
\text { length }(\mathrm{cm})\end{array}$ & No. of leaves \\
\hline \multicolumn{7}{|c|}{6 weeks } \\
\hline \multirow{4}{*}{ Full MS } & \multirow{2}{*}{ Shoot tip } & $\mathrm{BA}$ & 93.33 & $4.06 \pm 0.12^{\mathrm{a}}$ & $3.33 \pm 0.08^{\mathrm{a}}$ & $3.46 \pm 0.08^{\mathrm{a}}$ \\
\hline & & Kin & 76.66 & $2.46 \pm 0.12^{\mathrm{c}}$ & $2.43 \pm 0.08^{\mathrm{c}}$ & $2.23 \pm 0.08^{\mathrm{c}}$ \\
\hline & \multirow{2}{*}{$\begin{array}{c}\text { Axillary } \\
\text { node }\end{array}$} & $\mathrm{BA}$ & 86.66 & $3.66 \pm 0.14^{\mathrm{b}}$ & $3.10 \pm 0.05^{\mathrm{b}}$ & $3.10 \pm 0.05^{\mathrm{b}}$ \\
\hline & & Kin & 76.66 & $2.26 \pm 0.12^{\mathrm{c}}$ & $2.03 \pm 0.08^{\mathrm{d}}$ & $2.10 \pm 0.05^{\mathrm{c}}$ \\
\hline \multirow{4}{*}{ Half MS } & \multirow{2}{*}{ Shoot tip } & BA & 53.33 & $1.26 \pm 0.03^{\mathrm{e}}$ & $1.10 \pm 0.05^{\mathrm{f}}$ & $0.53 \pm 0.08^{\mathrm{d}}$ \\
\hline & & Kin & 40.00 & $1.60 \pm 0.05^{\mathrm{d}}$ & $1.36 \pm 0.08^{\mathrm{e}}$ & $0.00 \pm 0.00^{\mathrm{f}}$ \\
\hline & \multirow{2}{*}{$\begin{array}{l}\text { Axillary } \\
\text { node }\end{array}$} & BA & 56.66 & $1.20 \pm 0.10^{\mathrm{e}}$ & $1.06 \pm 0.03^{\mathrm{f}}$ & $0.30 \pm 0.05^{\mathrm{e}}$ \\
\hline & & Kin & 43.33 & $1.23 \pm 0.08^{\mathrm{e}}$ & $1.36 \pm 0.06^{\mathrm{e}}$ & $0.00 \pm 0.00^{\mathrm{f}}$ \\
\hline
\end{tabular}

Means \pm SE (standard error) in each column followed by same letters are not significantly different according to Dunchan's multiple range test (DMRT) at $\alpha=0.05$.

higher than in half strength MS medium.

\section{Multiple shoot formation}

Multiple shoot formation in Stevia rebaudiana requires adding cytokinins to the culture medium (Tadhani \& Rema, 2006). In vitro regenerated shoot buds from nodal explants were cultured on full strength MS medium with different concentrations $\left(0.5,1.0,2.0\right.$, and $\left.4.0 \mathrm{mgL}^{-1}\right)$ of BA or Kin. Data shown in Table 2 were revealed statistically significant differences between treatments at $5 \%$ level. Stevia rebaudiana could be established at control medium (free from PGRs) but with less effective response. The optimum number of shoot buds (4.46) and longest shoot $(3.63 \mathrm{~cm})$ without callus formation was occurred using $1.0 \mathrm{mgL}^{-1} \mathrm{BA}$ (Fig.1.B). This findings are in agreement with (Ahmad et al., 2011; Atalay et al., 2011 and Aman et al., 2013). While, using $2.0 \mathrm{mgL}^{-1} \mathrm{BA}$ gave 4.16 shoot buds and $3.30 \mathrm{~cm}$ shoot length. Whereas, using $0.5 \mathrm{mgL}^{-1} \mathrm{BA}$ found to be third best treatment recording 3.80 shoots/ explant and $3.13 \mathrm{~cm}$ shoot length. $0.5 \mathrm{mgL}^{-1} \mathrm{BA}$ was optimum, while the concentration more than $2.0 \mathrm{mgL}^{-1}$ reduced shoot number, shoot length and 
leaves number. Of the two cytokinins tested in this investigation, BA was found to be most efficient for shoot multiplication than Kin. However, MS supplemented with $0.5 \mathrm{mgL}^{-1}$ Kin observed 3.13 shoots/explant, $2.56 \mathrm{~cm}$ shoot length and 2.63 leaves number. Therefore, increasing the concentration of Kin more than $0.5 \mathrm{mgL}^{-1}$ reduced shoot number, shoot length and number of leaves.

Data presented in Table 2 is showing that the highest number of leaves/explant (3.70) was recorded when MS medium supplemented with $2.0 \mathrm{mgL}^{-1} \mathrm{BA}$ without significant differences with $1.0 \mathrm{mgL}^{-1} \mathrm{BA}$ (3.53), followed by $0.5 \mathrm{mgL}^{-1} \mathrm{Kin}$ recorded (2.63), then $0.5 \mathrm{mgL}^{-1} \mathrm{BA}$ that gave (2.36) without significant differences with 1.0 $\mathrm{mgL}^{-1} \mathrm{Kin}$ that observed (2.20) leaves number. On the other hand, callus formation could not be established at all tested concentration except

TABLE 2. Influence of different concentrations of BA and Kin on morphogenic responses of single-shoot explants of Stevia rebaudiana Bertoni established in vitro.

\begin{tabular}{|l|c|c|c|c|c|}
\hline $\begin{array}{l}\text { Plant growth } \\
\text { regulators }\end{array}$ & $\begin{array}{c}\text { Amount of } \\
\text { PGR (mg/l) }\end{array}$ & Shoots no./explant & $\begin{array}{c}\text { Average shoot } \\
\text { length }(\mathbf{c m})\end{array}$ & $\begin{array}{c}\text { Degree } \\
\text { of callus } \\
\text { formation* }\end{array}$ \\
\hline \multirow{4}{*}{ BA } & 0.0 & $1.26 \pm 0.06^{\mathrm{h}}$ & $1.26 \pm 0.08^{\mathrm{g}}$ & $1.16 \pm 0.03^{\mathrm{f}}$ & - \\
\cline { 2 - 6 } & 0.5 & $3.80 \pm 0.05^{\mathrm{c}}$ & $3.13 \pm 0.14^{\mathrm{b}}$ & $2.36 \pm 0.08^{\mathrm{c}}$ & - \\
\cline { 2 - 6 } & 1.0 & $4.46 \pm 0.08^{\mathrm{a}}$ & $3.63 \pm 0.08^{\mathrm{a}}$ & $3.53 \pm 0.08^{\mathrm{a}}$ & - \\
\cline { 2 - 6 } & 2.0 & $4.16 \pm 0.03^{\mathrm{b}}$ & $3.30 \pm 0.05^{\mathrm{b}}$ & $3.70 \pm 0.05^{\mathrm{a}}$ & - \\
\hline \multirow{4}{*}{ Kin } & 4.0 & $2.40 \pm 0.05^{\mathrm{f}}$ & $2.33 \pm 0.08^{\mathrm{d}}$ & $1.53 \pm 0.12^{\mathrm{de}}$ & + \\
\cline { 2 - 6 } & 0.5 & $3.13 \pm 0.08^{\mathrm{d}}$ & $2.56 \pm 0.03^{\mathrm{cd}}$ & $2.63 \pm 0.12^{\mathrm{b}}$ & - \\
\cline { 2 - 6 } & 1.0 & $2.73 \pm 0.08^{\mathrm{e}}$ & $2.66 \pm 0.08^{\mathrm{c}}$ & $2.20 \pm 0.11^{\mathrm{c}}$ & - \\
\cline { 2 - 6 } & 2.0 & $1.80 \pm 0.05^{\mathrm{g}}$ & $1.60 \pm 0.05^{\mathrm{e}}$ & $1.76 \pm 0.08^{\mathrm{d}}$ & - \\
\hline
\end{tabular}

*Callus formation (-, no callus; +, small callus less than $5 \mathrm{~mm}$ diameter; ++, moderate callus 5-10 mm diameter; +++, large callus more than $10 \mathrm{~mm}$ diameter). Data (Mean $\pm \mathrm{SE})$ recorded after 6 weeks.

the highest concentration $\left(4.0 \mathrm{mgL}^{-1}\right)$ of both $\mathrm{BA}$ and Kin, which produced small callus. Shoot bud proliferation and PGRs combination

At the same concentration of $1.0 \mathrm{mgL}^{-1} \mathrm{BA}$ but here in combination with different concentration of IBA or NAA $\left(0.1,0.5\right.$, or $\left.1.0 \mathrm{mgL}^{-1}\right)$ for multiple shoots bud proliferation different response were observed (Table 3). Among the tested combinations, a maximum initiation of healthy shoot buds (6.66) with higher shoot length $(4.46 \mathrm{~cm})$ were obtained within 6 weeks of culture using $1.0 \mathrm{mgL}^{-1} \mathrm{BA}+0.5 \mathrm{mgL}^{-1} \mathrm{IBA}$ combination followed by $1.0 \mathrm{mgL}^{-1} \mathrm{BA}+1.0$ $\mathrm{mgL}^{-1}$ IBA combination that gave (5.26) shoots/ explant and $(3.70 \mathrm{~cm})$ shoot length. $\mathrm{BA}\left(1.0 \mathrm{mgL}^{-}\right.$ $\left.{ }^{1}\right)+$ NAA $\left(1.0 \mathrm{mgL}^{-1}\right)$ combination proved to be the third best treatment recording (4.10) shoots/ explant and $(3.10 \mathrm{~cm})$ shoot length. The results are in agreement with Thiyagarajan \& Venkatachalam (2012), who noticed that $1.0 \mathrm{mgL}^{-1} \mathrm{BA}+0.5 \mathrm{mgL}^{-1}$ IBA combination was observed a good shoot bud development (4.25 shoots/explant) with $(5.02 \mathrm{~cm})$ shoot length. Addition of IBA along with BA has been reported to regenerate shoot buds from the nodal explants of Stevia rebaudiana (Atalay et al., 2011 and Aman et al., 2013) and in Jatropha curcas (Shrivastava \& Banerjee, 2008). In contrast, the present results are in disagreement with that of Abd Alhady (2011) and Deshmukh \& Ade (2012). However, using $0.5 \mathrm{mgL}^{-1} \mathrm{Kin}$ in the presence of $0.5 \mathrm{mgL}^{-1}$ IBA recorded (4.10 shoots/explant) with $(3.03 \mathrm{~cm})$ length. Of the two auxins tested in this experiment, IBA was proved to be the most efficient auxin for shoot multiplication compared to NAA. Increasing the concentration of NAA from 0.1 to $1.0 \mathrm{mgL}^{-1}$ in different combinations with $1.0 \mathrm{mgL}^{-1} \mathrm{BA}$ or $0.5 \mathrm{mgL}^{-1} \mathrm{Kin}$, increased the multiple shoot formation of Stevia rebaudiana. Moreover, Maharana et al. (2012) mentioned that cytokinins at the optimal concentration promotes shoot proliferations, and at high concentration stimulates meristems development and the inclusion of low concentration of auxins along 
TABLE 3. Influence of different concentrations and combination of PGRs on formation of multiple shoots Stevia rebaudiana.

\begin{tabular}{|c|c|c|c|c|c|c|}
\hline \multicolumn{4}{|c|}{$\begin{array}{l}\text { Plant growth regulators } \\
\qquad\left(\mathrm{mgL}^{-1}\right)\end{array}$} & Shoots no./explant & Shoot length $(\mathrm{cm})$ & $\begin{array}{l}\text { Degree of callus } \\
\text { formation }\end{array}$ \\
\hline BA & Kin & IBA & NAA & & & \\
\hline \multirow{6}{*}{1.0} & - & 0.1 & - & $3.23 \pm 0.12^{\mathrm{e}}$ & $3.00 \pm 0.05^{\mathrm{cd}}$ & - \\
\hline & - & 0.5 & - & $6.66 \pm 0.08^{\mathrm{a}}$ & $4.46 \pm 0.12^{\mathrm{a}}$ & - \\
\hline & - & 1.0 & - & $5.26 \pm 0.17^{b}$ & $3.70 \pm 0.11^{\mathrm{b}}$ & - \\
\hline & - & - & 0.1 & $2.63 \pm 0.08^{\mathrm{f}}$ & $2.13 \pm 0.08^{\mathrm{e}}$ & - \\
\hline & - & - & 0.5 & $3.66 \pm 0.12^{\mathrm{d}}$ & $2.36 \pm 0.14^{\mathrm{e}}$ & + \\
\hline & - & - & 1.0 & $4.10 \pm 0.05^{\mathrm{c}}$ & $3.10 \pm 0.05^{\mathrm{c}}$ & ++ \\
\hline- & \multirow{6}{*}{0.5} & 0.1 & - & $3.23 \pm 0.08^{\mathrm{e}}$ & $2.40 \pm 0.11^{\mathrm{e}}$ & - \\
\hline- & & 0.5 & - & $4.10 \pm 0.05^{\mathrm{c}}$ & $3.03 \pm 0.08^{\mathrm{cd}}$ & - \\
\hline- & & 1.0 & - & $3.50 \pm 0.11^{\mathrm{de}}$ & $2.76 \pm 0.14^{\mathrm{d}}$ & - \\
\hline- & & - & 0.1 & $1.73 \pm 0.08^{\mathrm{h}}$ & $1.20 \pm 0.05^{\mathrm{h}}$ & - \\
\hline- & & - & 0.5 & $2.26 \pm 0.08^{\mathrm{g}}$ & $1.53 \pm 0.08^{\mathrm{g}}$ & - \\
\hline- & & - & 1.0 & $2.60 \pm 0.11^{\mathrm{f}}$ & $1.83 \pm 0.03^{\mathrm{f}}$ & + \\
\hline
\end{tabular}

Data (Mean \pm SE )recorded after 6 weeks.

with cytokinins excites the shoot proliferation rate.

In this experiment, callus formation was observed in the presence of 0.5 and $1.0 \mathrm{mgL}^{-1} \mathrm{NAA}$ $+1.0 \mathrm{mgL}^{-1} \mathrm{BA}$ or in the combination between 1.0 $\mathrm{mgL}^{-1} \mathrm{NAA}+0.5 \mathrm{mgL}^{-1} \mathrm{Kin}$. However, adding IBA to the MS medium showed no callus and obtained elongated stems with well-developed leaves.

\section{In vitro root induction:}

Adventitious rooting is a critical factor for successful production of elite clones and important step in the plant species vegetative propagation, according to Davis \& Haissig (1994). In present study, regenerated shoots (1$1.5 \mathrm{~cm}$ long) were cultured on half MS basal salt without vitamins medium containing different concentrations of IBA or NAA $(0.1,0.5$, or 1.0 $\left.\mathrm{mgL}^{-1}\right)$. IBA and NAA significantly increased roots number/shoot and root length (Table 4). 0.5 $\mathrm{mgL}^{-1}$ IBA on half MS medium was found to be the optimum medium for root formation. it gave a good root formation $(83.33 \%)$, highest roots number/shoot (4.73), and a highest root length $(3.7 \mathrm{~cm})$ ) (Fig.1.C). Similar findings have also been reported for Citrus auriantifolia (Bhatt \& Tomar, 2010) and for Jatropha curcas (Toppo et $a l ., 2012)$ that indicate low concentrations of IBA $\left(0.5 \mathrm{mgL}^{-1}\right)$ proved to be more efficient for root formation. Then, $1.0 \mathrm{mgL}^{-1}$ IBA supplemented to MS medium proved to be second best treatment showing (4.46) root number/shoot with $(3.16 \mathrm{~cm})$ root length. This result was in agreement with Abd-Alhady (2011). However, the highest root formation percent $(93.33 \%)$ was recorded with 0.1 $\mathrm{mgL}^{-1} \mathrm{NAA}$ on half MS. Thus, the root formation percentage, roots number and root length were decreased by increasing NAA concentration more than $0.1 \mathrm{mgL}^{-1}$.

In contrast, results are disagree with those of Thiruvengadam \& Jayabalana (2000) on Vitex negundo, Jeyakumar et al. (2002) on Psoralea corylifolia and Deshmukh \& Ade 
TABLE 4. Influence of Auxins concentrations on adventitious root initiation of Stevia rebaudiana plant (half MS basal salt medium without vitamins was used).

\begin{tabular}{|c|c|c|c|c|c|}
\hline \multirow{2}{*}{$\begin{array}{c}\text { Amount of Auxin } \\
\left(\mathbf{m g L}^{-1}\right)\end{array}$} & $\begin{array}{c}\text { Root formation/shoot } \\
(\%)\end{array}$ & $\begin{array}{c}\text { Average growth } \\
\text { Roots no. / } \\
\text { shoot }\end{array}$ & $\begin{array}{c}\text { Root length } \\
(\mathbf{c m})\end{array}$ & $\begin{array}{c}\text { Callus } \\
\text { formation }\end{array}$ \\
\hline IBA & NAA & \multicolumn{3}{|c|}{} \\
\hline 0.0 & 0.0 & 90.00 & $2.33 \pm 0.14^{\mathrm{e}}$ & $1.20 \pm 0.05^{\mathrm{f}}$ & - \\
\hline- & 0.1 & 93.33 & $3.96 \pm 0.08^{\mathrm{b}}$ & $2.73 \pm 0.08^{\mathrm{c}}$ & - \\
\hline- & 0.5 & 86.66 & $3.53 \pm 0.12^{\mathrm{c}}$ & $2.30 \pm 0.05^{\mathrm{d}}$ & - \\
\hline- & 1.0 & 70.00 & $3.00 \pm 0.11^{\mathrm{d}}$ & $1.90 \pm 0.05^{\mathrm{e}}$ & - \\
\hline 0.1 & - & 63.33 & $3.03 \pm 0.17^{\mathrm{d}}$ & $1.43 \pm 0.12^{\mathrm{f}}$ & - \\
\hline 0.5 & - & 83.33 & $4.73 \pm 0.08^{\mathrm{a}}$ & $3.70 \pm 0.11^{\mathrm{a}}$ & - \\
\hline 1.0 & - & 76.66 & $4.46 \pm 0.08^{\mathrm{a}}$ & $3.16 \pm 0.12^{\mathrm{b}}$ & - \\
\hline
\end{tabular}

Data (Mean $\pm \mathrm{SE})$ recorded after 6 weeks.

(2012) on Stevia rebaudiana who reported in their studies that IAA was found to be more suitable hormone than IBA for root induction.

$0.5 \mathrm{mgL}^{-1}$ IBA in combination with three concentrations $\left(0.1,0.5\right.$, or $\left.1.0 \mathrm{mgL}^{-1}\right)$ of IAA, 2,4-D or NAA were used to study its influence on adventitious root formation (Table 5). The maximum number of roots (3.03) with longest roots $(5.30 \mathrm{~cm})$ were obtained with $0.5 \mathrm{mgL}^{-1} \mathrm{IBA}$ $+0.1 \mathrm{mgL}^{-1}$ IAA on half MS basal salts. However, the combination of $0.5 \mathrm{mgL}^{-1} \mathrm{IBA}+0.1 \mathrm{mgL}^{-1}$ NAA recorded the second best root number (2.70) without significant differences with $0.5 \mathrm{mgL}^{-1} \mathrm{IBA}$ $+0.5 \mathrm{mgL}^{-1}$ IAA that gave (2.66 roots). Increasing the concentration of IAA and NAA from 0.1 to $1.0 \mathrm{mgL}^{-1}$ in the presence of $0.5 \mathrm{mgL}^{-1} \mathrm{IBA}$ decreased roots number/shoot and root length. Once more, it could be noticed that the various concentrations of 2,4-D recorded the lowest values of root number and its length compared with the same concentrations of IAA or NAA. Thus, there

TABLE 5. Effects of different concentration and combination of auxins on adventitious root formation.

\begin{tabular}{|c|c|c|c|c|c|}
\hline \multicolumn{2}{|l|}{ Auxins } & $\begin{array}{c}\text { Amount } \\
\left(\mathrm{mgL}^{-1}\right)\end{array}$ & $\begin{array}{c}\text { Roots no./ } \\
\text { shoot }\end{array}$ & $\begin{array}{l}\text { Root length } \\
(\mathrm{cm})\end{array}$ & Degree of callus formation \\
\hline \multirow{9}{*}{ IBA $\mathbf{0 . 5}+$} & \multirow{3}{*}{ IAA } & 0.1 & $3.03 \pm 0.03^{\mathrm{a}}$ & $5.30 \pm 0.05^{\mathrm{a}}$ & - \\
\hline & & 0.5 & $2.66 \pm 0.08^{\mathrm{b}}$ & $4.16 \pm 0.06^{\mathrm{b}}$ & - \\
\hline & & 1.0 & $2.20 \pm 0.11^{\mathrm{c}}$ & $3.53 \pm 0.08^{c}$ & + \\
\hline & \multirow{3}{*}{$2,4-\mathrm{D}$} & 0.1 & $1.13 \pm 0.08^{\mathrm{f}}$ & $1.36 \pm 0.12^{\mathrm{g}}$ & - \\
\hline & & 0.5 & $1.60 \pm 0.05^{\mathrm{e}}$ & $1.73 \pm 0.12^{\mathrm{f}}$ & - \\
\hline & & 1.0 & $2.16 \pm 0.06^{\mathrm{c}}$ & $2.50 \pm 0.10^{\mathrm{e}}$ & ++ \\
\hline & \multirow{3}{*}{ NAA } & 0.1 & $2.70 \pm 0.11^{\mathrm{b}}$ & $3.46 \pm 0.08^{c}$ & - \\
\hline & & 0.5 & $2.26 \pm 0.08^{c}$ & $3.00 \pm 0.05^{\mathrm{d}}$ & + \\
\hline & & 1.0 & $1.90 \pm 0.05^{\mathrm{d}}$ & $2.40 \pm 0.17^{\mathrm{e}}$ & ++ \\
\hline
\end{tabular}

Data (Mean $\pm \mathrm{SE})$ recorded after 6 weeks. 
was no callus formation on IBA or NAA containing medium individually but in the presence of $0.5 \mathrm{mgL}^{-1}$ $\mathrm{IBA}+1.0 \mathrm{mgL}^{-1} \mathrm{IAA}, 1.0 \mathrm{mgL}^{-1} 2,4-\mathrm{D}, 0.5$ or/and $1.0 \mathrm{mgL}^{-1} \mathrm{NAA}$, much callus growth was formed.

\section{Acclimatization and field transfer}

The well-developed healthy in vitro rooted plantlets after 6 weeks were washed under tap water and hardened for ex vitro transplantation (Fig.1.D and E). The plantlets were planted into pots containing a mixture of organic soil and sand in (1 to 1$)$ ratio followed by placed it in a plastic tunnel and wetted with tap water and then covered with transparent plastic bags to preserve humidity. After 3 weeks, the established plants were transplanted to polyethylene bags containing garden soil and farmyard manure for further growth. The watering every two to three days if needed. The survival rate of in vitro propagated plantlets was $60-80 \%$ and plantlets grew very
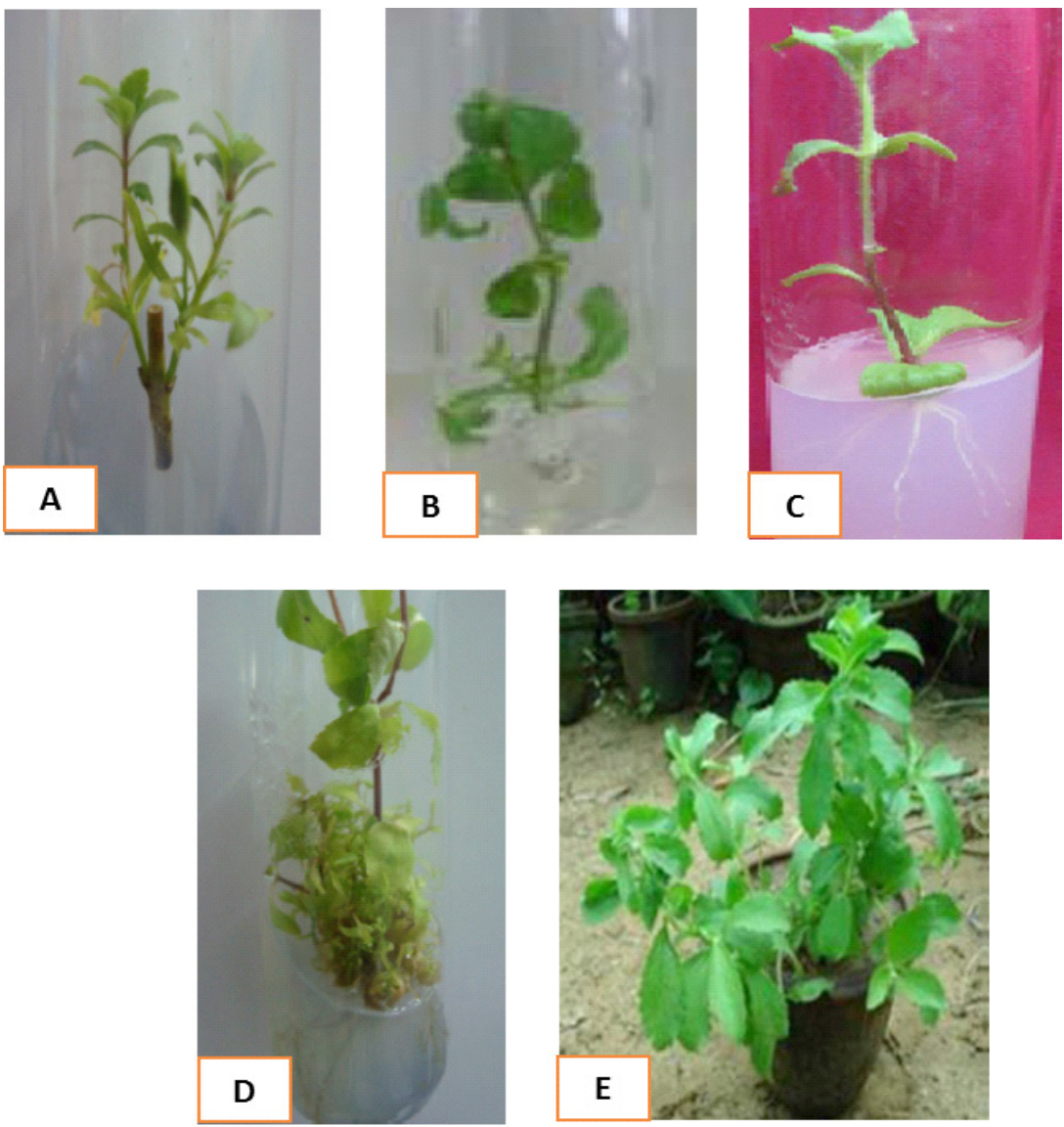

Fig. 1. (A) Axillary node explant of Stevia rebaudiana cultured on MS medium, (B) Multiple shoot formation, (C) in vitro root formation, (D) Multiple shoots with root formation, (E) in vitro propagated Stevia plantlet ready for field transfer

\section{REFERENCES}

Abd Alhady, M.R.A., (2011) Micropropagation of Stevia rebaudiana Bertoni. A new sweetening crop in Egypt. Global J. Biotech. \& Biochem. 6, 178-182.

Ahmad, N., Fazal, H., Zamir, R., Khalil, S.A. and Abbasi, B.H., (2011) Callogenesis and Shoot organogenesis from flowers of Stevia rebaudiana (Bert.). Sugar Tech. 13, 174-177.

Aman, N., Hadi, F., Khalil, S.A., Zamir, R. and Ahmad, N. (2013) Efficient regeneration for enhanced steviol glycosides production in Stevia rebaudiana
(Bertoni). Comptes Rendus Biologies. 336, 486-492.

Atalaya, E., Erisen, S., Yorgancilar, M. and Tanur, M., (2011) Micropropagation of Stevia rebaudiana Bertoni. Abstracts/Current Opinion in Biotechnology, 22, 135.

Bhatt, B. and Tomar, Y. (2010) Effects of IBA on rooting performance of Citrus auriantifolia Swingle (Kagzi-lime) in different growing conditions. Nat. Sci. 8, 8-11.

Davis, T. and Haissig, B., (1994) Biology of 
Adventitious Root Formation."Plenum Press, New York

Debnath, M., (2008) Clonal propagation and antimicrobial activity of an endemic medicinal plant Stevia rebaudiana. J. Med. Plant Res. 2, 45-51.

Debnath, M., Malik, C. and Pand, B.P.S. (2006) Micropropagation a tool for production of high quality plants based medicines. Pharm. Biotch. Curr. 7, 33-49.

Deshmukh, S. and Ade, R., (2012) In vitro rapid multiplication of Stevia rebaudiana: an important natural sweetener herb. Nusantara Bioscience, 4, 105-108.

Dey, A., Kundu, S., Bandyopadhyay, A. and Bhattacharjee, A. (2013) Efficient micropropagation and chlorocholine chloride induced stevioside production of Stevia rebaudiana Bertoni. Comptes Rendus Biologies, 336, 17-28.

Dhaka, N. and Kothari, S.L., (2005) Micropropagation of Eclipta alba (L.) Hassk. an important medicinal plant. In Vitro Cell. Dev. Biol. Plant, 41, 770-774.

Dyrskog, S., Jeppensen, P., Colombo, M., Abudula, R. and Hermansen, K., (2005) Preventive effects of a soy-based diet supplemented with stevioside on the development of the metabolic syndrome and type 2 diabetes in Zucker diabetic fatty rats. Metabolism. 54, 1181-1188.

Jeppensen, P.B., Gregerson, S., Poulsen, C.R. and Harmansen, K. (2002) Stevioside induces antihyperglycemic, insulinotropic and glucagonostatic effects in vivo: studies in the diabetic goto-kakizaki (gk) rats, Phytomedicine, 9, 9-14.

Jeyakumar, M. and Jayabalan, N. (2002) In vitro plant regeneration from cotyledonary node of Psoralea corylifolia L. Plant Tissue Cult. 12, 125-129.

Kartsonas, E. and Papafotio, M., (2007) Mother plant age and seasonal influence on in vitro propagation of Quercus euboica Pap., an endemic, rare and endangered oak species of Greece. Plant Cell Tiss. Org. Cult. 90, 111-116.

Kinghorn, A.D. and Soejarto, D.D. (1985) Current status of stevioside as a sweeting agent for human use. In: Economical and Medicinal Plant Research", Wanger H., Hikino H., Farnsworth N.R. (Ed.) Vol.1, pp.1-52.

Maharana, S.B., Mahato, V., Behera, M., Mishra, R.R. and Panigrahi, J. (2012) In Vitro regeneration from node and leaf explants of Jatropha curcas L. and evaluation of genetic fidelity through RAPD markers. Indian Journal of Biotechnology, 11, 280-287.

Murashige, T. and Skoog, F. (1962) A revised medium for rapid growth and bioassays with tobacco tissue cultures. Physiol. Plant. 15, 473-497.

Nakamura, S. and Tamura, Y. (1985) Variation in the main glycosides of Stevia (Stevia rebaudiana Bertoni). Jpn. J. Trop. Agric. 29, 109-116.

Patil, V., Reddy, P.C., Purushotham, M.G., Prasad, T.G. and Udayakumar, M. (1996) In vitro multiplication of Stevia rebaudiana. Curr. Sci. 70, 960.

Shrivastava, S. and Banerjee, M. (2008) In vitro clonal propagation of physic nut ( $J$. curcas L.): Influence of additives. Inter J. of Integr. Biol. 3, 73-79.

Singh, S.D. and Rao, G.P. (2005) Stevia: the herbal sugar of $21^{\text {st }}$ century. Sugar Tech. 7, 17-24.

Sivaram, L. and Mukundan, U. (2003) In vitro culture studies on Stevia rebaudiana. In vitro Cell. Dev. Biol. Plant. 39, 520-523.

Starratt, A.N., Kirbyb, C.W., Posca, R. and Brandle, J.E. (2002) Rebaudioside F, a diterpene glycoside from Stevia rebaudiana. Phytochemistry, 59, 367.

Tadhani, M.B. and Rema, S. (2006) In vitro antimicrobial activity of Stevia rebaudiana Bertoni leaves. Trop. J. Pharma. Res. 5, 557-560.

Tamura, Y., Nakamura, S., Fukui, H. and Tabata, M., (1984) Clonal propagation of Stevia rebaudiana Bertoni by stem-tip culture. Plant Cell Report, 3, 180185.

Thakur, R.C. and Karnosky, D.F. (2007) Micropropagation and germplasm conservation of central park splendor Chinese elm trees. Plant Cell Rep. 26, 1171-1177.

Thiyagarajan, M. and Venkatachalam, P. (2012) Large scale in vitro propagation of Stevia rebaudiana (Bert.) for commercial application: pharmaceutically important and antidiabetic medicinal herb. Ind. Crops and Prod. 37, 111-117.

Thiruvengadam, M. and Jayabalan, N. (2000) Mass propagation of Vitex negundo L. In vitro J. Plant Biotech. 2, 151-155.

Thomas, T.D. and Shankar, S. (2009) Multiple shoot induction and callus regeneration in Sarcostemma 
brevistigma wight and Arnott, a rare medicinal plant. Plant Biotech. Rep. 3, 67-74.

Toppo, D.D., Singh, G., Purshottam, D.K. and Misra, P. (2012) Improved in vitro rooting and acclimatization of Jatropha curcas plantlets. Biomass and Bioenergy J. 44,42-46
Uddin, M.S., Chowdhury, M.S.H., Khan, M.M.H., Uddin, M.B., Ahmed, R. and Baten, M.A.(2006) In vitro propagation of Stevia rebaudiana Bert in Bangladesh. Afr. J. Biotech. 5(13), 1238-1240.

\title{
بروتوكول كفء وفعال لإنتاج واكثار نبات الاستيفيا على نطاق واسع
}

\author{
احمد سعد عطايا \\ قسم الإنتاج النباتي - كلية العلوم الزراعية البيئية - جامعة العريش - شمال سيناء- مصر.
}

\begin{abstract}
يعتبر نبات الاستيفيا من المحليات الطبيعية ذات القيمة العالية ونبات طبي يحتوي على المركبات المحلية داخل

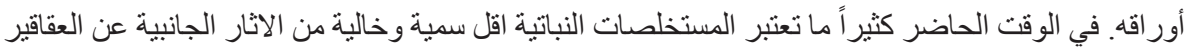

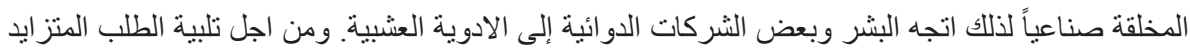

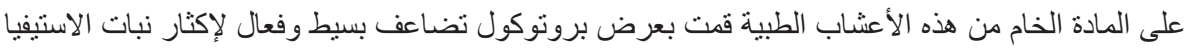

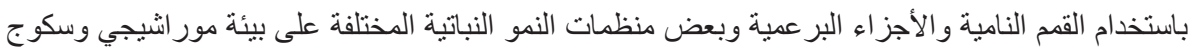
للحصول على نباتات صحية وذات معدل انتاج وفير.

تم الحصول على معدل نمو خضري مثالي ذات عدد كبير من البراعم الخضرية وبدون تكوين الكالس

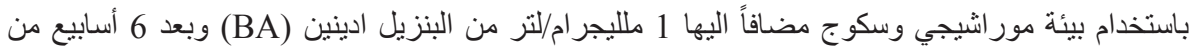
الزر اعة حيث أعطت 4.06 - 4.46 بر عم خضري للمنفصل النباتي الو احد. كذلك تفوقت التوليفة المكونة من 1 التون

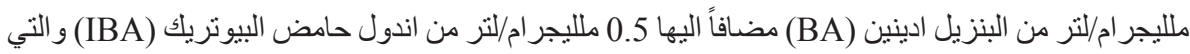
أعطت معدل 6.66 بر عم خضري للمنفصل النباتي الو احد ومعدل طول للبر عم بلغ التغ 4.46 سم.

كذلك فان الأجزاء الخضرية الصحية التي تمت استطالتها تم زراعتها على نصف قوة بيئة مور اشيجي

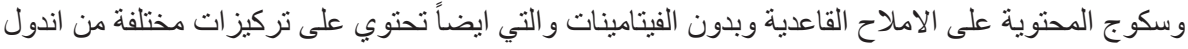

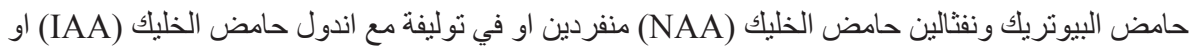

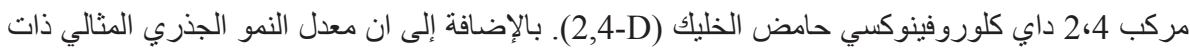

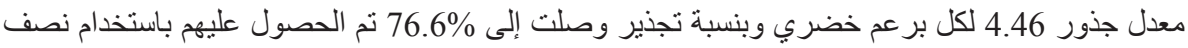

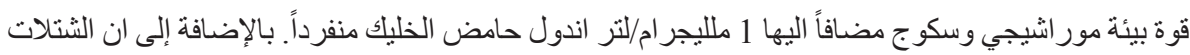

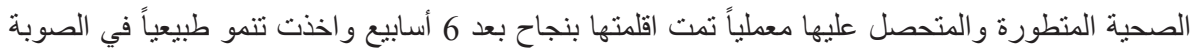

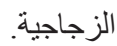

